\title{
'Alapaha' Rabbiteye Blueberry
}

\author{
D. Scott NeSmith ${ }^{1}$ \\ Department of Horticulture, Georgia Station, Griffin, GA 30223-1797
}

\section{Arlen D. Draper ${ }^{2}$ and James M. Spiers ${ }^{3}$ \\ USDA-ARS, Small Fruit Laboratory, Poplarville, MS 39470}

Additional index words. Vaccinium ashei, fruit breeding, cultivar, ripening date

'Alapaha' is a rabbiteye blueberry (Vaccinium ashei Reade) being jointly released by the University of Georgia College of Agricultural and Environmental Sciences, the Univ. of Georgia Agricultural Experiment Station, and the U.S. Dept. of Agriculture. Named after the Alapaha River in south Georgia, 'Alapaha' ripens early in the rabbiteye season along with V. ashei 'Climax' (Brightwell and Draper, 1975), yet blooms at least a week later. The later blooming is important because 'Climax' has received moderate to severe freeze damage during bloom in south Georgia for at least 4 of the last 10 years. The fruit of 'Alapaha' are medium sized, high quality, and can be mechanically harvested. 'Alapaha' introduces an additional cytoplasm (from $V$. ashei 'Walker') into the gene pool for rabbiteye blueberry cultivars.

\section{Origin}

'Alapaha', tested as T-256, was selected in 1972 at the Coastal Plain Experiment Station in Tifton, Ga., from a cross of T-65 x V. ashei 'Brightwell' (Austin and Draper, 1983) made in Beltsville, Md., by Arlen Draper (Fig. 1). This is the first rabbiteye blueberry cultivar released that has cytoplasm from the wild $V$. ashei clone 'Walker'. 'Alapaha' was evaluated for a number of years at the Univ. of Georgia's Blueberry Research Farm near Alapaha, Ga. In 1992, 'Alapaha' was tested in the Southern Regional Blueberry Evaluation Trial at diverse locations including Alapaha, Ga., Clarksville, Ark. (Univ. of Arkansas' Fruit Substation Research Farm), and Poplarville, Miss. (USDA-ARS Small Fruit Laboratory). Data from 10 site-year combinations indicate that 'Alapaha' is widely adapted to areas conducive to rabbiteye blueberry production.

Received for publication 15 Oct. 2001. Accepted for publication 10 Feb. 2002. A contribution of the Univ. of Georgia Agricultural Experiment Station, Georgia Station, Griffin, and USDA-ARS, Poplarville, Miss. This research was supported, in part, by state and Hatch Act funds allocated to the Georgia Agricultural Experiment Stations. We gratefully acknowledge the efforts of Dr. John Clark and associates at the Univ. of Arkansas in testing this blueberry selection. The senior author also is greatly appreciative of the financial support provided to the blueberry cultivar development program at the Univ. of Georgia by MBG Marketing and by the Univ. of Georgia Research Foundation's Cultivar Development Program.

${ }^{1}$ Professor.

${ }^{2}$ Research Geneticist, retired.

${ }^{3}$ Research Horticulturist.

\section{Description and Performance}

'Alapaha' has been primarily compared with the early season rabbiteye standard 'Climax'. In Alapaha, Ga., and Clarksville, Ark., productivity of 'Alapaha' substantially exceeded that of 'Climax' each year (Table 1). In fact, the 4-year average yield for 'Climax' in south Georgia was only $61 \%$ of that of 'Alapaha'. In Poplarville, Miss., 'Alapaha' production equaled or exceeded that of 'Climax'. Some of the increased production of 'Alapaha' has been due to its later bloom time as compared to 'Climax', especially in south Georgia, which lessens the risk of spring freeze damage during bloom (Table 2). The later

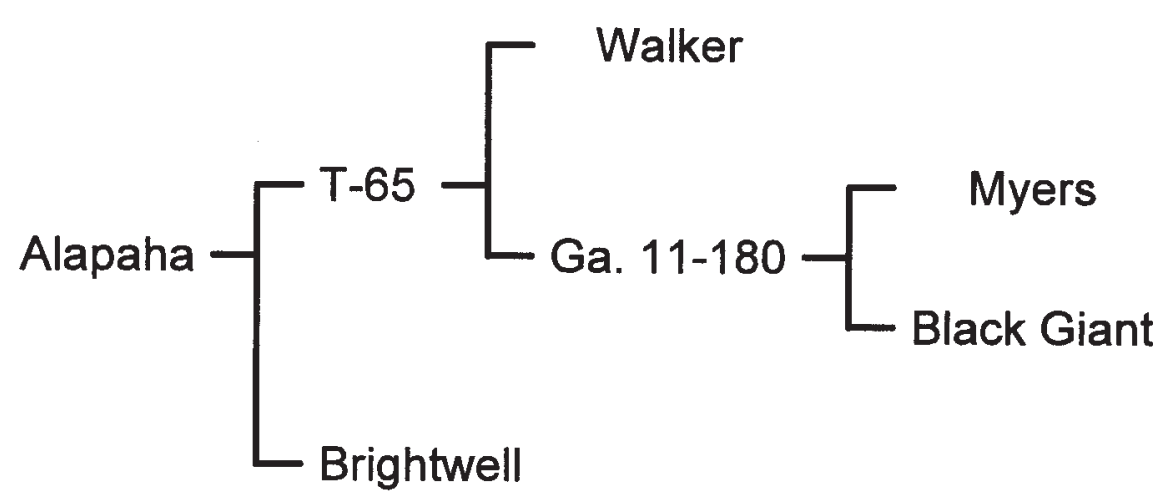

Fig. 1. Pedigree of 'Alapaha' rabbiteye blueberry.

Table 1. Yield of 'Alapaha' and 'Climax' rabbiteye blueberries. Data are from single bush, replicated plots at Alapaha, Ga., Clarksville, Ark., and Poplarville, Miss. Plants were established at each location in 1992 as part of a Southern Regional Blueberry Evaluation Trial. Yields are totals from multiple harvests.

\begin{tabular}{lccc}
\hline \hline & \multicolumn{2}{c}{ Selection } & \\
\cline { 2 - 3 } Location/Year & Alapaha & Climax & Significance $^{2}$ \\
\cline { 2 - 3 } Alapaha, Ga. & \multicolumn{2}{c}{$\mathrm{kg} / \mathrm{bush}$} & \\
1998 & 5.2 & 3.0 & $*$ \\
1999 & 6.1 & 2.8 & $*$ \\
2000 & 6.8 & 5.1 & $*$ \\
2001 & 5.7 & 3.6 & $*$ \\
4-year average & 6.0 & 3.6 & \\
Clarksville, Ark. & & & $*$ \\
1997 & 5.8 & 2.8 & $*$ \\
1998 & 8.8 & 1.8 & $*$ \\
3-y99 & 11.0 & 5.5 & \\
Poplarville, Miss. & 8.5 & 3.4 & \\
1997 & & & $*$ \\
1998 & 4.5 & 3.9 & NS \\
1999 & 0.9 & 1.0 & $*$ \\
3-year average & 4.1 & 2.9 & \\
\hline
\end{tabular}

${ }^{2}$ Significantly different at the $5 \%$ probability level $(*)$, or not significantly different (NS). bloom time of 'Alapaha' is not coupled with an equal delay in ripening, however, which Therefore, one of the most important advantages of 'Alapaha' is that it blooms at least a week after 'Climax', yetripens before or within a few days of 'Climax'.

The estimated chill requirement of 'Alapaha' is $500 \mathrm{~h}$ below $7^{\circ} \mathrm{C}$. This is derived from comparing the bloom date of 'Alapaha' f its parents) and 'Climax' over a 4-year period (Table 3). 'Climax' has a chill requirement of 400 to $450 \mathrm{~h}$, and 'Brightwell' has a reported requirement of $400 \mathrm{~h}$, although 'Brightwell' bloom date generally coincides with cultivars requiring 500 to 550 chill hours (Austin, 1994; Krewer and NeSmith, 2001). Berry quality and plant vigor subjective ratings of 'Alapaha' and 'Climax' for each of 3 years at Alapaha, Ga., are listed (Table 4). Ratings were on a scale of $1=$ poorest to $10=$ best, with a value of 7 considered "commercially acceptable" for various characteristics including size, scar, color, firmness, and flavor (Morrow et al., 1949). In addition, 3-year average attributes from the Arkansas and Mississippi locations of the 1992 Southern Regional Blueberry Evaluation Trial are depicted 
Table 2. Bloom and ripening dates of 'Alapaha' and 'Climax' rabbiteye blueberries. Data are from replicated plots at Alapaha, Ga., Clarksville, Ark., and Poplarville, Miss. Plants were established at each location in 1992 as part of a Southern Regional Blueberry Evaluation Trial. Dates are estimates of $50 \%$ bloom and ripening.

\begin{tabular}{|c|c|c|c|c|}
\hline \multirow[b]{2}{*}{ Location/Year } & \multicolumn{4}{|c|}{ Selection } \\
\hline & Alapaha & Climax & Alapaha & Climax \\
\hline & \multicolumn{2}{|c|}{-Date of $50 \%$ bloom- } & \multicolumn{2}{|c|}{-Date of $50 \%$ ripening - } \\
\hline \multicolumn{5}{|l|}{ Alapaha, Ga. } \\
\hline 1998 & 15 Mar. & 4 Mar. & 5 June & 2 June \\
\hline 1999 & 23 Mar. & 16 Mar. & 7 June & 2 June \\
\hline 2000 & 17 Mar. & 8 Mar. & 31 May & 31 May \\
\hline 2001 & 8 Mar. & 1 Mar. & 25 May & 31 May \\
\hline \multicolumn{5}{|l|}{ Clarksville, Ark. } \\
\hline 1997 & 4 Apr. & 1 Apr. & 26 June & 26 June \\
\hline 1998 & 13 Apr. & 11 Apr. & 22 June & 23 June \\
\hline 1999 & --- & --- & 28 June & 27 June \\
\hline \multicolumn{5}{|c|}{ Poplarville, Miss. } \\
\hline 1997 & 18 Mar. & 12 Mar. & 19 June & 26 June \\
\hline 1998 & 17 Mar. & 7 Mar. & 5 June & 1 June \\
\hline 1999 & --- & --- & 8 June & 9 June \\
\hline
\end{tabular}

Table 3. Estimated chill hours $\left(<7^{\circ} \mathrm{C}\right)$ from 1 Oct.-15 Feb. and dates of bloom for 'Alapaha', 'Brightwell', and 'Climax' in south Georgia for 4 years.

\begin{tabular}{|c|c|c|c|c|}
\hline \multirow[b]{2}{*}{ Year } & \multirow{2}{*}{$\begin{array}{l}\text { Estimated } \\
\text { chill hours }\end{array}$} & \multicolumn{3}{|c|}{ Selection } \\
\hline & & Alapaha & Brightwell & Climax \\
\hline & & & te of bloom & 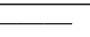 \\
\hline 1997-98 & 625 & 15 Mar. & 26 Mar. & 4 Mar. \\
\hline 1998-99 & 400 & 23 Mar. & 29 Mar. & 16 Mar. \\
\hline 1999-00 & 720 & 17 Mar. & 18 Mar. & 8 Mar. \\
\hline $2000-01$ & 970 & 8 Mar. & 5 Mar. & 1 Mar. \\
\hline
\end{tabular}

Table 4. Ratings of berry and plant attributes of 'Alapaha' and 'Climax' rabbiteye blueberries for each of 3 years from replicated plots at Alapaha, Ga. Ratings are on a scale of $1=$ poorest to 10 = best, with a value of 7 generally considered "commercially acceptable". Plants were established in 1992 as part of a Southern Regional Blueberry Evaluation Trial.

\begin{tabular}{|c|c|c|c|c|c|c|}
\hline \multirow[b]{2}{*}{ Plant attribute } & \multicolumn{2}{|c|}{$1999^{z}$} & \multicolumn{2}{|c|}{2000} & \multicolumn{2}{|c|}{2001} \\
\hline & Alapaha & Climax & Alapaha & Climax & Alapaha & Climax \\
\hline Berry size & $7.0 \mathrm{a}$ & $7.0 \mathrm{a}$ & $7.2 \mathrm{a}$ & $7.0 \mathrm{a}$ & $7.0 \mathrm{a}$ & $7.0 \mathrm{a}$ \\
\hline Berry scar & $8.0 \mathrm{a}$ & $8.0 \mathrm{a}$ & $8.0 \mathrm{~b}$ & $8.5 \mathrm{a}$ & $8.5 \mathrm{a}$ & $8.0 \mathrm{~b}$ \\
\hline Berry color & $7.0 \mathrm{~b}$ & $8.0 \mathrm{a}$ & $7.4 \mathrm{~b}$ & $7.9 \mathrm{a}$ & $7.5 \mathrm{~b}$ & $8.0 \mathrm{a}$ \\
\hline Berry firmness & $8.0 \mathrm{a}$ & $8.0 \mathrm{a}$ & $7.4 \mathrm{~b}$ & $8.4 \mathrm{a}$ & $8.0 \mathrm{a}$ & $8.0 \mathrm{a}$ \\
\hline Berry flavor & $7.5 \mathrm{~b}$ & $8.0 \mathrm{a}$ & $8.0 \mathrm{a}$ & $8.0 \mathrm{a}$ & $8.0 \mathrm{a}$ & $8.0 \mathrm{a}$ \\
\hline Plant vigor & $9.0 \mathrm{a}$ & $8.0 \mathrm{~b}$ & $9.8 \mathrm{a}$ & $9.3 \mathrm{~b}$ & $9.0 \mathrm{a}$ & $9.0 \mathrm{a}$ \\
\hline
\end{tabular}

${ }^{\mathrm{z} A t t r i b u t e s}$ of cultivars within a year followed by the same letter were not significantly different at the $5 \%$ probability level.

Table 5. Three-year (1998-2000) average ratings of berry and plant attributes of 'Alapaha' and 'Climax' rabbiteye blueberries at Clarksville, Ark., and Poplarville, Miss. Ratings are on a scale of $1=$ poorest to $10=$ best, with a value of 7 "commercially acceptable." Plants were established at each location in 1992 as part of a Southern Regional Blueberry Evaluation Trial.

\begin{tabular}{lccccr}
\hline & \multicolumn{2}{c}{ Clarksville, Ark. } & & \multicolumn{2}{c}{ Poplarville, Miss. } \\
\cline { 2 - 3 } \cline { 5 - 6 } Plant attribute & Alapaha & Climax & & Alapaha & Climax \\
\hline Berry size & $7.1 \mathrm{a}$ & $7.1 \mathrm{a}$ & & $7.1 \mathrm{a}$ & $7.2 \mathrm{a}$ \\
Berry scar & $9.6 \mathrm{a}$ & $8.8 \mathrm{~b}$ & & $7.6 \mathrm{a}$ & $7.8 \mathrm{a}$ \\
Berry color & $7.2 \mathrm{~b}$ & $8.0 \mathrm{a}$ & & $7.5 \mathrm{a}$ & $7.6 \mathrm{a}$ \\
Berry firmness & $8.2 \mathrm{a}$ & $8.1 \mathrm{a}$ & & $7.3 \mathrm{a}$ & $7.3 \mathrm{a}$ \\
Berry flavor & $7.1 \mathrm{a}$ & $6.7 \mathrm{a}$ & & $7.4 \mathrm{~b}$ & $7.9 \mathrm{a}$ \\
Plant vigor & $7.3 \mathrm{a}$ & $6.8 \mathrm{~b}$ & & $7.0 \mathrm{~b}$ & $7.5 \mathrm{a}$ \\
\hline
\end{tabular}

${ }^{\mathrm{z}}$ Attributes of cultivars for a given location followed by the same letter were not significantly different at the $5 \%$ probability level.

(Table 5). 'Alapaha' and 'Climax' were very similar in berry ratings. The only consistent difference was that 'Climax' color was slightly better (more blue) than 'Alapaha', although, 'Alapaha' color is good.

The bush type of 'Alapaha' is very similar to 'Brightwell' (one of its parents). It is vigorous and upright, with a fairly narrow crown.
Leafing of 'Alapaha' is better than 'Climax', even following mild winters. 'Climax' is known to be a poor leafing cultivar, which causes problems with fruit sizing in some years (Williamson et al., 2001). 'Alapaha' easily produces sufficient stems to "renew" the plant. Some twig dieback has been observed on 'Alapaha' in south Georgia, but during 4 years of observations this has not caused serious problems. Propagation of 'Alapaha' has been easily accomplished from softwood cuttings.

'Climax' is considered, by the Georgia industry, as a standard cultivar for mechanical harvesting of rabbiteye fruit for the fresh market. In 1999, tests of mechanical harvesting of 'Climax' and 'Alapaha' were conducted in south Georgia (NeSmith et al., 1999). The data suggested that 'Alapaha' would be suitable for mechanical harvesting, with fruit losses and firmness losses being similar to 'Climax'.

'Alapaha' may be self-fertile to a degree, similar to 'Brightwell' (NeSmith, 1999). However, 'Alapaha' should be planted with another rabbiteye cultivar with a similar blooming period for cross pollination. The recent release V. ashei 'Austin' (Hall and Draper, 1997) would likely be a good choice for planting with 'Alapaha'. Vaccinium ashei 'Premier' would be suitable as well. 'Climax' is a poor choice for cross-pollination of 'Alapaha' in south Georgia because it blooms earlier.

\section{Availability}

A U.S. Plant Patent for 'Alapaha' has been applied for on behalf of the Univ. of Georgia Research Foundation. Contact the Georgia Seed Development Commission, 2420 S. Milledge Ave., Athens, GA 30606, for information on plant source and availability. Neither the Georgia Agricultural Experiment Station nor the USDA-ARS have plants for distribution.

\section{Literature Cited}

Austin, M.E. 1994. Description of cultivars, p. 1424. In: M.E. Austin. Rabbiteye blueberries. AgScience, Auburndale, Fla.

Austin, M.E. and A.D. Draper. 1983. 'Brightwell' rabbiteye blueberry. HortScience 18:252.

Brightwell, W.T. and A.D. Draper. 1975. The 'Bluebelle' and 'Climax' rabbiteye blueberries. Fruit Var. J. 29:44.

Hall, M.R. and A.D. Draper. 1997. 'Austin' rabbiteye blueberry. HortScience 32:1295-1296.

Krewer, G. and D.S. NeSmith. 2001. Blueberry cultivars for Georgia. Posted at: http:// w w w.s mallfruits . org/GrowerInfo/ BlueberryCultiv.htm.

Morrow, E.B., G.M. Darrow, and J.A. Rigney. 1949. A rating system for evaluation of horticultural material. Proc. Amer. Soc. Hort. Sci. 53:276280.

NeSmith, D.S. 1999. Response of 'Brightwell' rabbiteye blueberry to self and cross pollination. A 1999 research report, p. 30-32. In: D.S. NeSmith (ed.). Blueberry research at the University of Georgia. Res. Rpt. 662. Univ. of Georgia College of Agr. and Environ. Sci., Athens.

NeSmith, D.S., S.E. Prussia, and G. Krewer. 1999. Response of some rabbiteye and southern highbush blueberries to mechanical harvesting. A 1999 research report, p. 17-20. In: D.S. NeSmith (ed.). Blueberry research at the University of Georgia. Res. Rpt. 662. Univ. of Georgia College of Agr. and Environ. Sci., Athens.

Williamson, J.G., B.E. Maust, and D.S. NeSmith. 2001. Timing and concentration of hydrogen cyanamide affect blueberry bud development and flower mortality. HortScience 36:922-924. 